\title{
Comparative Analysis of General Words-Terms In Persian and Uzbek Languages
}

\author{
Khulkar Vasilovna Mirzakhmedova \\ $\mathrm{PhD}$, Associate professor,Tashkent State University of Oriental Studies
}

\section{ABSTRACT}

According to the history, the Persian language is one of the oldest languages in the world that has not lost its features. Following a different times and historical conditions, Persian words, as well as the Arabic language, influenced the vocabulary of other languages. The vocabulary of the Uzbek language is no exception in this process. From ancient times, the use of the Persian-Tajik language was observed side by side with the languages of the countries of Mawarannahr, in particular with the Uzbek language. As a result, many words from the Persian and Arabic languages were integrated into the lexical structure of the Uzbek language, that is, they are used as general words in both Persian and Uzbek languages. However, not all general words are used to express the same meaning.

There are such original Persian words in the Uzbek language, the semantic border of which has a different meaning in the Persian language, while in the Uzbek language it has a different meaning. It is important to note that these words-terms used in both languages refer to the active speech layer in these languages. In addition, the ways of formation of those general words in comparable languages must comply with international standards. As a result of such studies, clarity is introduced into the questions of the etymological basis and the semantic boundary of general words in the Persian and Uzbek languages.

For example, in the Uzbek language, there are a number of general words-terms, such as "оромгох" (“сатр”), “дехқон” (“farmer”), “дастак” (“lever”), “тухумдон” (“ovary”), “хонанда” (“singer”), “олийгох" ("university") and “лашкаргох" ("military camp"), which do not express meaning as in the Persian language. Even today, these words are general words expressing the features of terms that have been proposed and already have been introduced instead of Russian-international words. A semantic and functional study of such words will contribute to the development of Uzbek lexicology. Because after giving the status of "state language" to the Uzbek language in 1989, the task became to take care of its authority. Accordingly, this article aims to cover the structuralsemantic analysis of general Persian words-terms used today in the Uzbek language.

Keywords: term-word, general word, Persian, Uzbek, borrowing.

Article Received: 10 August 2020, Revised: 25 October 2020, Accepted: 18 November 2020

\section{INTRODUCTION}

It is known that in the early twentieth century, according to the theoretical and scientific views and proposals developed by the Vienna, Prague and Russian schools of terminology in world terminology, an international standard has emerged in general linguistics, which can be applied to all languages. Prior to that, a number of standardization associations were established, such as ISA (International Association for Standardization), British Standard Institution
(ISO), ISO (International Organization for Standardization). The activities of these organizations are combined with the International Standard of Terminology - ISO 704 (hereinafter - the International Standard). It was republished in 2000 with standard amendments [1, 2000]. It contains instructions on the boundaries of the term, its reflection in normative documents, the term and the principle of its definition, term formation, and standardization of terminology. 
In the East, especially in Iran, three "language academies" have been established over time to preserve the purity of language. The latter is the third academy, which was founded in 1991 and now has its own Guidelines for the creation and presentation of the term. At the same time, in 1991, the "Atamakom" for Uzbek language terminology began its work and completed its work in a short period of time.

The main goal of both organizations the Academy and the "Atamakom" - was to preserve the purity of the language in the country, to replace the acquisitions with an alternative to the national language.

At this point, in terms of the principle of operation, it is not difficult to understand the difference between the two organizations:

1) The Academy continued its work as a logical successor to the activities of the first language academy formed in 1936 in Iran;

2) "Atamakom" had to work to preserve the purity of the language by removing Russian-international words from the Uzbek language, which were part of the Uzbek language dictionary during the former Soviet era.

However, no matter how hard you try, you will definitely learn a certain language. In particular, Persian words occupy a significant share in the lexical structure of the Uzbek language, which is common to Persian-Tajik language since ancient times. Therefore, we have chosen to analyze the terms that have entered the Uzbek language from the Persian language today, but have different meanings in terms of semantic space.

Objectives and tasks: Based on the results of etymological and structural analysis of common words used in both Persian and Uzbek languages, the aim was to show the semantics and levels of application. In order to achieve this goal, the following tasks have been identified:

-combination of common words in Persian and Uzbek languages; -determine the etymology of common words in Persian and Uzbek from annotated dictionaries;

-carrying out structural analysis of common words in Persian and Uzbek languages;

-determine the semantic field of common words in Persian and Uzbek languages;

- clarify the level of use of common words in Persian and Uzbek languages.

Methods: The article used comparative, analytical methods.

\section{THE MAIN FINDINGS AND RESULTS}

The development of science and technology, as well as the political situation in Uzbekistan, has played a significant role in changing the structure of the Uzbek language dictionary. As a result of neologisms, the constant use of Russian-international terms, the lexical units that exist in the Uzbek language have become a passive layer. Later, in 1989, a year after the Uzbek language was granted the status of the state language, in 1990; the Terminology Committee was established under the Cabinet of Ministers of the Republic of Uzbekistan. Thus, many socio-political and economic terms, such as "muxtoriyat" (autonomy), "ma'muriyat" (administration), "ma'mur" (administrator), "muqobil" (alternative), "hakam" (arbitrator), "tashrif" (visit), "insonparvarlik" (humanity), "xususiylashtirish" (privatization), "boshboshdoqlik" (anarchy), "iqtisodiyot" (economy), "ma'lumotnoma" (reference), "reja" (plan), "dastur" (program), "kengash" (cuncil) which were previously used in the Uzbek language and were familiar to the society, were re-introduced. However, in these times, there was also some confusion and errors in the replacement and use of terms. Terminology-specific norms have not always been followed. An attempt has been made to forcibly squeeze previously successfully used terms out of circulation, replacing them with lexical units that do not meet the laws of word formation. Studying and analyzing these issues can become another object of research. 
The opposite also happened: when the Persian and Arabic dialects, which were previously used in the Uzbek language and became a passive layer, were transformed into an active layer of speech, the etymological meaning of the word was ignored and lexical structure was involved. Today, the lexical fund of the Uzbek language has many Persian, Arabic, Turkish borrowings, as well as common terms, some of which do not have meaning in their semantic field, and at the same time, the frequency of use is high.

There are a number of common terms used today in both Persian and Uzbek, such as "oromgoh", "dexqon" (farmer), "dastak" lever, "tuxumdon" (ovary), "xonanda" (singer), "oliygoh" (high institution), "lashkargoh" (military camp), the etymology of which is Persian or Arabic, but in terms of content they have different meanings when used in both languages. Below we analyze such terms.

For example, it is derived from آرام ārām Pahlavi in آرامخاءāāmgohwords in Persian, the original Persian word representing "tinchlanish" (calm), "to'xtash" (stop), "qotish" (freeze), "harakatsizlik" (motionless), "ohista" (slow) meanings [2, 2010]. As a result of the addition of gāhsemi-affixes that make up the name of the place, آرامَآ $\bar{a} \bar{a} m g \bar{a} h$ words were formed, meaning "quiet place". However, the word is used in Persian to mean "mausoleum":

[3, 2008].

$$
\text { آرامعاه ابو على ابن سينا در شهر همدان (ايران) }
$$

Ārāmgāh-e abu Ali ibn Sinā dar šahre hamadān (Irān) ast.

"The tomb of Abu Ali ibn Sina is in Hamadan (Iran)".

In Uzbek, the same term "oromgox" "rest area" is used to mean "dam oladigan joy" (resting place), "lager" (camp) and "park" (garden).

Happy summer children's camp serves about 300 children every summer [4, 2008].

In the explanatory dictionary of the Uzbek language, the word "oromgox" "rest area" comes from the Persian language and has the meanings "dakhma", "maqbara" (mausoleum) in Persian, but it has the following two meanings:

1) A place where people can rest, relax;

2) A place built for school children to rest during the summer holidays [5].

It should be noted that the word "oromgox" "rest area", which exists in both languages, but is semantically different, is of Persian origin.

It is known that any language develops, first of all, on the basis of its capabilities. At the same time, countries, colorful international relations are an important factor in the emergence of mastery of any language. This phenomenon is not uncommon for the Uzbek language. Some of them have not lost their activity in the general lexicon. However, in terms of usage, a single common word has a small percentage of meanings in both languages. For example, the word "dexqon" (farmer), which has been used in Uzbek for a long time, is in fact derived from Persian, and the following meanings are given in dictionaries:

1) "qishloq egasi" (owner of village), "qishloq xoni" (khan of village);

2) “qishloq xo'jaligi” (agricultural household) [6, 2010];

3) "qishloqliklar" (rural people) -

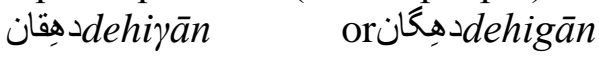
(dahigān) [7, 1395].

"Now our farmers are working hard and earning a lot of money," said the hero of Uzbekistan D. Abdullayev [8, 2017].

The word, which is now actively used in Uzbek, originally came into Uzbek from Persian, but today it has become a passive speech lexicon in Persian.

On the initiative of Atamaqom, the Uzbek language was not able to express its opposite attitude to the process of entering Arabic-Persian words-terms, which were previously not used and did not meet the vocabulary of the Uzbek language, but were published in the press as an alternative to the 
Uzbek language, and even suggested the use of such Mastering by Atamaqom. As a result, such terms and terminology began to be used in the press. This led to a number of misunderstandings in the Uzbek language lexicon:

1) It was suggested to use both assimilation and its equivalent in the Uzbek language;

2) The main principle of terminology contributed to the development of the phenomenon of synonymy;

3) There was a problem of "ikkilanish" (hesitation) (ie, which of the synonyms to use in the language) in the press;

4) Eventually, the term proposed in the lexicon began to go out of use.

This indicates that the activities of Atamakom in the Uzbek language are poorly organized.

Thus, another Persian word - "dastak" (lever) is now used in Uzbek for two terms:

1) In Russian "rychag" ("The handle of the mill ear")

2) "dasta" (lever), "sop" (handle), "tutqa" (knob).

It is also used in a figurative sense: "dalil" (courageous), "hujjat" (document), "asos" (base) [8].

It should be noted that these دستى dastakare original Persian artificial words (دستdast "hand" and - -akdiminutive affixes), and their explanatory dictionaries have two meanings:

1) Small hand, reduced hand;

2) "Bloknot" (notebook), a notebook carried in a wallet $[10,2010]$.

Both meanings of these دستى dastakwords in Persian are not semantically appropriate for the two terms used in the Uzbek language - "ruchka" (pen) and "rychag" (handle).

It was mentioned above that the Uzbek language uses a large number of Arabic and Persian-Tajik dialects. Some of these have not lost their activity in the general lexicon.
In particular, "chorraha" (intersection), "sumalak" (sumalak), "maktab" (school), "sinf" (class), "muallim" (teacher), "ma'ruza" (lecture), "muvozanat" (balance), "vazn" (weight), "tijorat" (trade), "bojxona" (customs), "viloyat" (region), "falak" (sky), "huquq" (right), "tarkib" (content), "matn" (text), "mavzu" (text), "hokim" (authority) and other similar Persian and Arabic terms and words are actively used not only by experts, but also by the general public without any difficulties in speech. Although Arabic and Persian-Tajik languages are almost nonexistent as a source in the process of creating terms in Uzbek, as in other related Turkic languages, most of the terms in the Uzbek dictionary belong to these ancient languages. These assimilations, in accordance with the phonetic and grammatical rules of the Uzbek language, acquire new content and serve to express new concepts.

Since the principle of minimum differentiation is important in terminology $[11,1985]$, from the point of view of the grammar of the acquired language, the acquisitions are not divided into morphemes (meaningful parts), but enriched with suffixes or prefixes within the scope of the acquired language and take place in the lexicon.

In this regard, paragraph 2 of the statute of the Atamaqum contains the following theoretical points: "In creating and regulating terms in the Uzbek language, it is desirable to use the internal capabilities of the native language, including the possibilities of making words and dialects of the bunda Uzbek language, to be considered the main criterion and fully comply with the rules of spelling" [12, 1992].

In this respect, the Uzbek language of Atamaqom has introduced a number of terms, which are derived from the use of wordbuilding methods. For example, like "gazet(a)"-"gazetxon"-"gazetachi"; "jurnal""jurnalxon"-"jurnalist"-"jurnalistika". At this point, another problem began to appear in Uzbek terminology: the term "ro'znoma", "haftanoma", "oynoma", "jarida", "majalla", which had previously been introduced to the same assimilation, could not participate in the 
process of word formation on its own. Thus, the same terms, originally Persian and Arabic, introduced by Atamakom for the lexicon of the Uzbek language, began to disappear from the language on their own. Nevertheless, a certain number of Persian and Arabic words remained in the Uzbek language.

There is another term that we want to analyze, the etymology of which is based on the Pahlavi language, that is, the original Persian word - تخمدانtoxmdān(تخمtoxm "eggs" and - - - dānaffixes) "ovary". Explanatory dictionaries explain the meaning of this term as follows:

1) in biology: the shell part, located in the core of the flower, where the flower seeds are stored;

2) a pit prepared for sowing seeds;

3) a reproductive organ located in the internal body of animals [13].

[14, 2007]

$$
\text { درون تخمدان ها دانه هاى كوجكى به وجود }
$$

Darun-e toxmdānhā dānehā-ye kučeki be vojud miyāyad ke ...

"Outside the ovaries, a small seed (grain) is formed ...".

The term "tuxumdon" (ovary) is now used in Uzbek to mean "a member of the human body".

Speaking in the Uzbek language in the context of "words", "assimilations", in Article 5 of the old version of the Law of the Republic of Uzbekistan "On the state language" adopted in 1989, the following sentences could be found:

Article 5: In the activities of public authorities and administration of the Republic of Uzbekistan, congresses, plenums, congresses, sessions, conferences, meetings and councils are conducted in the state language of the republic and provided with accurate translation.

Meetings in labor collectives are held in the state language, as well as in the language chosen by the members of the assembly [15, 1989].
We would like to draw your attention to the fact that the words highlighted in this article are the same Russian, Turkish and Arabic assimilations. This situation is almost non-existent in the new version of the Law in 1995:

Article 8: Documents of local authorities and administration are accepted and published in the state language. In densely populated areas, documents of local authorities are adopted and published in the state language of the republic and in the language of the nation [16].

This means that even when the Law on the State Language was adopted (1989), Uzbek words were not used in their entirety.

As a result of the status of the Uzbek language as the "state language", a number of attempts to replace the Russian-international dialects became apparent. As a result, undeveloped re-acquisition was proposed. For example, the term "airport" was replaced by the terms "tayyoragoh", "bandargoh", the term "institute" was replaced by the words "olyiygoh", "ilmgoh" (higher institution), the term "journal" was replaced by "oynoma", "majlla", "oybitik"; it is recommended to use the words "valyuta" instead of "chet pul" (foreign currency), "business" instead of "pultopar" (money earning), "archive" instead of "hujjatasrov" (document keeping), "notarius" - instead of "nusxakash" copy man, "transport" instead of "naqliyot", "attestation" instead of "malakasinov" (qualificational test) was found. The artificiality of such new constructions was distinguished by the fact that the norms of term creation did not meet. As a result of such haste, unscientific terms appeared in the system of Uzbek terminology, which led to the strengthening of synonymy in the structure of terms. At the same time, almost all of them left the Uzbek language.

In Persian, the word خو انندان xannande"reader" (the modern basis of the verb "read" خوان xān خوان xāndan and the suffix - نده - ande - adjective) means "qo'shiqchi" (singer) when used in Uzbek. As can be seen, the meaning of the common 
word used to indicate a different meaning in Persian is unique in Uzbek.

It is worth noting the term "university" (proposed instead of "institute" or "university"), which was proposed at that time, but in terms of its formation does not meet the requirements of the norm of word formation. The term "higher institution" is "high" (derived from عالى âliArabic, a group of adjectives meaning "katta" (big), "yuqori" (high), "boozorgvor") and - ك̌_ -gāh (Persian semi-affix that makes a place name), based on the model "quality + affix" made.

It should be noted that the international standard ISO 704 [17, 2000], which proposes the rules of term formation for all languages, does not have a model of word formation "quality + affix (semi-affix)". In particular, آلى كاه âligāh words of "higher education" were not observed in either Persian or Arabic. Thus, the word is formed from the combination of the Arabic base (عالى âli - - adjective) and Persian suffixes (كاهى $-g \bar{a} h$ semi-affixes denoting place names) in the Uzbek language itself.

The above has analyzed a number of common Persian words and phrases in the Uzbek and Persian languages that exist only in the original Persian language, assimilated into the Uzbek language and far from its original meaning. In addition, the Uzbek language has such common words that they are formed in such models as "Arabic basis + Persian affix (semi-affix)", "Persian basis + Arabic affix". Such terms can include many constructions such as "ma'lumotnoma" (reference note), "guvohnoma" (certification), "arabshunos" (Arabic researcher), "ta'mirtalab" (repair needed), "og'ufurush" (Drug Diller). The grammaticalmorphological, lexical and structural analysis of common words based on these patterns is the subject of another article.

\section{CONCLUSION}

On October 4, President of the Republic of Uzbekistan Sh.M. Mirziyoev signed a resolution on the worthy celebration of the 30th anniversary of the Law "On the state language". According to the resolution, according to this historic document, over the past years, the Uzbek language has gained a solid legal basis and high status. Currently, the Uzbek language is actively used in public administration, interstate relations, science, education, medicine, culture and art. Therefore, defining the semantic field of words and terms used in the Uzbek language and clarifying the limits of their use will be a great contribution to the development of the Uzbek language in the future.

There are such pure Persian words in Uzbek that their spiritual boundary has a different meaning in Persian, while in Uzbek it has a completely different meaning. Interestingly, this term, which is used in both languages, refers to the active speech layer in both languages. In addition, the methods of making the same words in the languages being compared must conform to an international standard. As a result of such research, the etymological basis of common words in Persian and Uzbek languages and the boundary meaning of artificial words will be clarified.

\section{REFERENCES}

[1]. Terminology work - Principles andMethods //InternationalStandardISO704. Second edition 2000-11-15. Reference number ISO 704:2000 (E). - 38 p.

[2]. Amid H. (2010) Farhang-e farsi-ye amid. -1389 h/sh. S. 25. // Amid H. Persian Dictionary of Amid/. - P. 25.

[3]. Tarix-e Iran dar yek negah. -Tehran, 1387 h/sh. S.34. // Iranian history at a glance. Tehran. 2008. - p. .34.

[4]. http://www.summer.uz

[5]. A. Madvaliev. The National Encyclopedia of Uzbekistan. - p. 139. // www.ziyouz.com Library.

[6]. Amid H. Farhang-e farsi-ye amid. -1389 h/sh. S. 39. // Amid H. Persian Dictionary of Amid/ -2010. - P. 25.

[7]. Hasan Dust M. (1395) Farhang-e Risheshenasi-ye zaban-e farsi. Jeld-e dovvom. P-D Farhangestan-e zaban va adabiyot-e farsi. -Tehran. 1385. 
[8]. http://www.uza.uz>documents>rizqrozimiz-bunyodkori-bo-lgan-09-12-2017

[9]. Annotated dictionary of Uzbek language. Edited by A. Madvaliev. National Encyclopedia of Uzbekistan. - p. 571. // www.ziyouz.com kutubxonasi.

[10]. Amid H. (2010) Farhang-e farsi-ye amid. -1389 h/sh. S. 252. // Amid H. Persian Dictionary of Amid. - P. 252.

[11]. Begmatov E. Lexical layers of modern Uzbek language. -Tashkent: Science, 1985. p.103.

[12]. Republican terminology committee under the Cabinet of Ministers of the Republic of Uzbekistan. -Tashkent. 1992. pp. 4-6.
[13]. Amid H. (2010) Farhang-e farsi-ye amid. -1389 h/sh. S. 331. // Amid H. Persian Dictionary of Amid. - P. 331.

[14]. Giyahishenasi-ye gol-e golab sas. Tehran, 2007. S.31. // Botany of rose flower. Tehran, 2007. - p. 31.

[15]. Law of the Republic of Uzbekistan "On State Language" (1989). Available at: http://www.lex.uz/acts

[16]. On introducing amendments and addenda to the Law of the Republic of Uzbekistan "On State Language". Available at: http://www.lex.uz/acts/121051

[17]. Terminology work - Principles andMethods //InternationalStandardISO704. Second edition 2000-11-15. Reference number ISO 704:2000 (E). 